\title{
Hasan Ali Yücel: A Leader Transforming Turkish Education and Culture between Years 1938 and $1946^{1}$
}

\author{
Gökhan KILIÇOĞLU \\ Derya YILMAZ \\ Selahattin TURAN \\ Eskişehir Osmangazi University, Faculty of Education
}

\begin{abstract}
Biographic studies provide long term perspectives on leadership, learning of leadership attributes and its development. It is clear that life story of a leader is an important source of information that provides followers with information about the traits and behaviors of the leader. Thus, the current study seeks to offer an in-depth look at transformational leader attributes of Hasan Ali Yücel, one of the prominent intellectuals of the Republican period in history of Turkey, from the perspective of Bass and Avolio (1993). Based on the public documents (e.g., archival materials, books and journals written by Yücel and other authors), biographies, photographs and speeches, four general frames of transformational leadership; idealized influence and charisma, inspirational motivation, intellectual stimulation and individualized consideration were handled to reveal transformational leader characteristics of Hasan Ali Yücel.
\end{abstract}

Keywords: transformational leadership, cultural change, Hasan Ali Yücel, Turkish Education System.

\section{INTRODUCTION}

Transformational leadership has captured the interest of many researchers in the field of organizational leadership over the past decades. Transformational leadership theory was developed by Burns (1978) and enhanced by Bass $(1985,1998)$ and other researchers (Avolio \& Bass, 1988; Bass \& Avolio, 1994; Bennis \& Nanus, 1985; Tichy $\&$ Devanna, 1986). The major premise of the transformational leadership theory is said to be the leader's ability to guiding and motivating followers to work toward common goals (Bass, 1985). Indeed, transformational leadership encompassess various aspects such as emphasizing motivation and development of followers, raising awareness, highlighting priorities, fosterinf moral maturity of followers, creating ethical climate, encouraging folloeers to common good, promoting cooperation, providing coaching and mentoring for followers, appealing to the ideals of followers. Thus, it is concluded that transformational leadership has four components: idealized influence, inspirational motivation, intellectual stimulation, and individualized consideration (Bass, 1985).

\footnotetext{
${ }^{1}$ A part of this study was presented at the $7^{\text {th }}$ National Congress on Education Administration held in Inönü University, on 24-26 May 2013
} 
When the related literature is examined, it is clear that a wide variety of different research methods have been employed in the research on transformational leadership. Normative and instrumental approaches have been dominated these leadership studies (Leithwood, 1994; Yammarino \& Bass, 1990). Most of the research has been utilized Multiple Leadership Questionnaire (MLQ) developed by Bass and Avolio (1995), stemming from leader behavior and how it affects followers' motivation, job satisfaction and performance (Yukl, 2010). Specifically, transformational leadership is found to be associated with the personal outcomes of the followers (Barling, Moutinho \& Kelloway, 1998; Hatter \& Bass, 1988; Kirkpatrick \& Locke, 1996) and organizational outcomes (Barling, Weber \& Kelloway, 1996; Boerner, Eisenbeiss \& Griesser, 2007; Howell \& Avolio, 1993; Jorg \& Schyns, 2004). Research has shown that transformational leadership have an effect on follower satisfaction (Koh, Steers \& Terborg, 1995), commitment to the organization (Barling et al., 1996; Koh et al.) and commitment to organizational change (Yu, Leithwood \& Jantzi, 2002). Over the last years, it is clear that scholars in the education field have emphasized transformational leadership traits of leaders in educational setting by utilizing qualitative research methods through interviewing (Balyer, 2012; Veland, 2012; Xavier, 2013). As it is clear from the literature, transformational leadership studies provide ample information about that leadership style and its relations with other variables. However, studies describing the characteristics of transformational leaders with representative behaviors and statements are limited in qualitative studies. Thus, biographical and narrative approach to leadership studies should complement the dominant emphasis on leadership styles because real world details and constitutive roles in structuring social action and actors are neglected by these normative and instrumental approaches (Gronn \& Ribbins, 1996; Shamir, Dayan-Horesh \& Adler, 2005). Specifically, two methodological approaches for searching leadership studies; namely biography and ethnography are ignored in leadership research. In fact, there are some ways in which biographies and ethnographic evidences facilitate theorizing leadership. Furthermore, biographic studies unveiling the genesis and value frameworks and work styles of leaders are developed while ethnographic studies clarify situational dynamics of leader followership. Ethnographic observation of leaders in natural setting provides an accurate understanding of why particular individuals are attributed as leaders by the followers and how these leaders sustain or weaken their leadership status over time. Biographic studies provide long term perspectives on leadership, learning of leadership attributes and its development (Gronn \& Ribbins, 1996). Therefore, it is obvious that life story of a leader is an important source of information that provides an information for the followers about the traits and behaviors of the leader (Shamir, Dayan-Horesh \& Adler, 2005).

When the history of Republic of Turkey is examined, transformation movement in Turkish education system is said to begin with Hasan Ali Yücel since he was a successful educator, politician and a delicate person in Turkish culture and education history. At the same time, Yücel was an enlightened leader aiming to transform the society with his charisma by embodying this character in his personality. Throughout ninety-two years Republic period, he was the only person serving seven years, seven months and seven days as the minister of national education with successful duties, innovative practices and great steps transforming the Turkish culture. It is clear that Hasan Ali Yücel motivated members of Turkish Republic to transcend people's selfinterests in order to achieve collective educational objectives and to meet needs of the society. Therefore, Hasan Ali Yücel can be said to be a model of integrity and fairness, 
setting clear roles, having high expectations, providing opportunity, and getting people to look their beyond their needs and reach for higher goals. Therefore, it is significant to examine that important person in history of Turkish education with his leadership qualities. From this standpoint, one of the prominent intellectuals of the Republican period in history of Turkey, Hasan Ali Yücel is aimed to be scrutinized whether he can be considered as a transformational leader. Thus, the current study seeks to offer an indepth look at transformational leader attributes of Hasan Ali Yücel from the perspective of Bass and Avolio (1993). First of all, it is necessary to mention at this point, who is Hasan Yücel and what is his life story that is worth telling.

\section{Hasan Ali Yücel: Educator Having a Heart in East, a Mind in West}

Hasan Ali Yücel who was borned in 1897 in Istanbul was the founder of the main institutions in current Turkish education system with his achievements in the fields of education, culture, aesthetic and art. Hasan Ali Yücel was the former minister of education of Turkey, serving from December 1938 to August 1946 with 7 years, 7 months and 7 days service reputation throughout the minister of education history. He was proven in history of Turkish education by his character and reforms. Yücel was an honest, clear and simple person with having a consistent and strong character. At the same time, he was also accepted as an effective speaker possessing principled and reliable personality with being an enlightened person internalizing cultures of east and west. His ideas and works in the ministry still have influence on many areas of education and social life in Turkey since he facilitated to built a new society after the foundation of Turkish Republic. He gave inspiration and direction to enlightenment project of Turkey by leading educational reform efforts in education system (Coşkun, 2007; Çıkar, 1998; Yücel, 1990).

During his service as a minister, he provided First National Congress of Education with scientists, educators, writers, and artists and First Turkish Publishing Exhibition in order to discuss problems of education and to create solutions. He was also established National Bureau of Translation to present world classical works to Turkish citizens and provided several symposiums by setting initiatives in the fields of Grammar and Alphabet, Antiquities and Museums, Sports and Physical Education, Vocational and Technical Education. Yücel assigned educators to edit and publish Islam Encyclopedia which was later turned to Turkish Encyclopedia and facilitated to publish journals in the field of education, art and various areas of culture. In order to encourage artists to art and introduce contemporary music, theatre, opera, ballet to Turkish citizens, he organized Public Painting and Sculpture Exhibition for the first time and pioneered establishment of State Conservatory in Ankara. Within his service, he provided works regarding the standardization and purification of Turkish language for education to become spare and clean. Furthermore, he restructured Ministry of National Education and performed initiatives for the establishment of vocational and technical schools. Yücel also gave importance to higher education; Higher Education Act was authorized, universities were set sovereignty and higher education institutions became autonomous, universities and faculties were established in his service period. Yet, his main and important achievement was Village Institutes which were established to serve education in rural areas for uneducated citizens, to graduate teachers for other districts and to improve life standards of the villages (Coşkun, 2007; Çıkar, 1998, Yücel, 1990). 
When the related literature is reviewed, there is limited number of study conducted about the leadership of Hasan Ali Yücel even though his life and achievements were subject of many books. On the other hand, there are not much biographical studies concerning transformational leadership. Research on transformational leadership seems to be heavily shaped within positivist paradigm. In this study, transformational leadership behaviors of Hasan Ali Yücel who was Minister of National Education (1938-1946) and made the most effective educational reforms in Turkey was examined from Bass and Avolio’ point of view.

\section{Theoretical Framework}

Researchers dealing with management became to be interested in emotional and symbolic aspects of leadership in 1980s. By means of emphasizing these aspects, one can easily acknowledge how leaders affect their followers through self-sacrifying and putting forward needs of the mission or organization rather than their self-interest. In fact, this important aspect of leadership can be described with transformational leadership theories (Yukl, 2010).

Transformational leadership involves processes comprising change and transforming people through accomplishing more than what are expected of them. More specifically, transformational leadership deals with emotions, values, standards, long term goals, motivation, and satisfaction of personal needs by treating people as human being (Northouse, 2007). Actually, the first transformational leadership term was firstly introduced by Downtown (1973). Afterwards, political sociologist James MacGregor Burns and his book entitled Leadership (1978) emphasized political leadership. In his work, Burns tried to connect the roles of leadership and followers considering the followers' needs and raising higher levels of motivation and morality. Indeed, Burns gives importance to humanistic psychology by proposing that transforming leader shapes and changes his followers' motives, values and goals.

In the mid-1980s, Bernard M. Bass (1985, p. 20) provided first formal theoretical presentation of transformational leadership in his book titled Leadership and Performance Beyond Expectations by extending Burn's work emphasizing followers' needs rather than the leaders'. In his book, Bass presents three functions characterizing transformational leaders. First, transformational leaders raise followers' awareness and level of consciousness about importance of their task and the importance of performing well. Second, followers are being aware of their level of need for personal growth and success by transformational leaders. The third function, transformational leaders motive followers to transcend their personal interest for the good of the organization. By means of that, followers are motivated to do more than they had previously expected to do. However, Bass provides one-way transformation from leader to followers while Burns perceives transformational leadership as a two-way process (Bolden, Gosling, Marturano \& Dennison, 2003). Different from Burns, Bass also deals with transformational style of executive leadership incorporating social change.

From perspective of Bass, transformational leaders increase needs of their followers, transcend followers' self-interest, raise their confidence, encourage behavioral change, increase their expectations and motive followers for personal achievement (Bass, 1985, 1990). In fact, transformational leadership occurs when leaders elevate interests of their subordinates, generate awareness and acceptance of the group mission and purposes with providing the perception of looking behind the self- 
interest for the good of the group. However, Bass (1990) states that these results can be achieved through being charismatic to the followers with inspiring them because being charismatic gives the person great power and influence, high degree of trust and confidence, and subordinates want to identify with him. Furthermore, emotional needs of the followers can be met since and/or subordinates can be stimulated intellectually via providing willing and showing new ways of looking at old problems and teaching followers that problems can be solved with rational solutions.

Dynamics of transformation process is elaborated through providing a model of transformational and transactional model by Bass and Avolio (1990, 1993, 1994). According to Bass and Avolio, transformational leadership includes four factors: charisma or idealized influence (attributed or behavioral), inspirational motivation, intellectual stimulation, and individualized consideration (Bass, 1985, 1998; Bass \& Avolio, 1993).

Charisma or Idealized Influence: This factor describes the leader acting with a strong role model for the followers with envisioning, being confident, building others' respect and setting high standards for rivalry. These leaders consider moral and ethical issues, talk about the importance of trusting each other, and emphasize most important values and beliefs. In fact, charisma provides a vision and a sense of mission with specifying the importance of having a strong sense of purpose. These leaders also instill pride to people for being associated with them and reassure others to go beyond their selfinterest for the good of the group (Bass, 1985, 1998; Bass \& Avolio, 1993).

Inspirational Motivation: The second factor inspirational motivation describes leaders who talk optimistically about the future and communicate high expectations to followers. In order to be committed and a part of shared vision in the organization, followers are also inspired through motivation by leaders with enhancing team spirit. In addition, transformational leaders express important purposes in simple ways, articulate confidence that goals will be achieved, and use symbols to focus members' efforts for achieving more than they would do in their own interest (Bass, 1985, 1998; Bass \& Avolio, 1993).

Intellectual Stimulation: This factor covers leadership by promoting intelligence, rationality and careful problem solving. Specifically, this leadership stimulates followers to be creative and innovative with a leader having an orientation to be rational, empirical, existential and idealistic. This leader needs to be capable of solution generation and encourage followers to seek different perspectives when solving organizational problems. Indeed, this type of leadership supports new ways of looking and engages non-traditional thinking while engaging with problems (Bass, 1985, 1998; Bass \& Avolio, 1993).

Individualized Consideration: The last factor emphasizes developmental orientation with giving personal attention, treating each follower individually, coaching and advising. This factor actually includes leadership that provides supportive climate with spending time for teaching and coaching by giving attention to individualization through considering individuals' different needs, abilities and aspirations from others as 
well as a sense of ownership and personal responsibility, helping followers to develop their strengths for their self development (Bass, 1985, 1998; Bass \& Avolio, 1993).

Transformational leadership appears to involve a process in which leaders raise awareness of members in the organization as regards what is right and important, increase motivation and take action to go beyond members' self-interests for the good of the group by making personal sacrifices for others' benefit, elevate members' maturity level of the needs from security to self-development and achievement (Bass \& Avolio, 1994). In fact, transformational leadership engages with purposes, values, morals and ethics, focuses on missions and strategies, and releases human potential by identifying and developing new talents (Covey, 1992).

Transformational leadership may be in the form of changes in macro level in social systems as well as being seen at micro level among individuals (Yukl, 2010). Since education lies behind the transformation of social systems, leading people in education are needed to reach future's information society adapting to changes brought by the era and to implement changes into practice.

\section{METHOD}

\section{Research Design}

This research presents a biographical study aiming to analyze Hasan Ali Yücel who was Minister of National Education between years 1938 and 1946 in Turkey, from the perspective of transformational leadership. Biographical study is a form of narrative study that involves the study of a single individual and his or her experiences as told to the researcher or as found in documents and archival materials (Denzin, 1989). Indeed, narrative is a specific type of qualitative design which provides an account of a chronologically connected an event or action, or series of events or actions (Czarniawska, 2004). Specifically, narrative may also an extended story about a significant aspect of one's life (Chase, 2005). Narrative studies with a specific contextual focus may be guided by a theoretical lens or perspective (Creswell, 2007, p.55). Therefore, this study provides leadership behaviors of Hasan Ali Yücel from transformational leadership perspective via documents and archival materials.

\section{Procedure}

This narrative study uncovering the experiences of Hasan Ali Yücel about his transformational leadership behaviors is considerably lean on documents. In document research, the issues involve public documents (e.g., archival materials, books and journals written by Yücel and other authors), biographies, photographs and speeches of Yücel from First National Congress of Education, Second National Congress of Education to First Publication Congress.

Five practical stages that are followed when using, accessing and utilizing documents were used in the study. These stages are access, checking for authenticity, understanding the documents, analyzing and utilizing the data (Forster, 1995). More specifically, the choice of documents was determined by considering transformational leadership behaviors perspective that we were trying to investigate, and where these data are to be obtained were explored. In terms of checking for authenticity, genuine and original primary sources like speeches, books and journals were utilized. While 
understanding the documents, interpretations were placed on transformational leadership behaviors of Yücel considering the perspective of Bass and Avolio (1993) in a systematic way. Lastly, primary public sources were chosen and the presented information in these documents about Yücel's transformational leadership was quoted considering the citation rules while utilizing the data. Furthermore, general existing themes and codes of transformational leadership driven from Bass's perspective (Bass, 1984) were developed deductively in this study (Miles \& Huberman, 1994). The research data was reviewed by the researchers depending on the existing themes through reaching authentic and original resources. In order to ensure definitional clarity, as well as reliability, two experts performed independent examination of entire research process from data gathering to data analysis for determining to what extent the findings are not influenced by biases (Lincoln \& Guba, 1985; Miles \& Huberman, 1994).

\section{FINDINGS}

Characteristics and behaviors of Hasan Ali Yücel from the perspective of transformational leadership model (Bass, 1984) are presented in Table 1. Four general frames of transformational leadership; idealized influence and charisma, inspirational motivation, intellectual stimulation and individualized consideration were handled and sub-categories were given place under these frames.

Table 1

Characteristics and behaviors of Hasan Ali Yücel emerged from transformational leadership model

\begin{tabular}{llll}
\hline $\begin{array}{l}\text { Charisma and idealized } \\
\text { influence }\end{array}$ & $\begin{array}{l}\text { Inspirational } \\
\text { motivation }\end{array}$ & $\begin{array}{l}\text { Intellectual } \\
\text { stimulation }\end{array}$ & $\begin{array}{l}\text { Individualized } \\
\text { consideration }\end{array}$ \\
\hline -Vision & & -Creativity & -Considering \\
-High level goals & -Source of & -Problem solving & individual needs \\
-Forward thinking & inspiration & -A new perspective & -Importance to \\
-Role model & -Internalization & -Opportunity & growth \\
-Respect and admiration & -Team spirit & providing & -Accepting \\
-Moral and ethical standards & & & differences \\
\hline
\end{tabular}

\section{Creating a Vision and Setting High Level Goals for Education}

Charismatic leaders analyze the existing situation effectively and create a vision with high level goals by drawing picture of the future. In Yücel period, Turkey was quite inferior in terms of both quality and number of teachers. After 15 years passing World War I, implications of economic depression emerged in education; difficulties about primary education dissemination in the villages were faced. According to 1935 census, literacy rate for males were $\% 23.3$ and females were $\% 8.2$; number of children attending to school was $\% 80$ in cities and $\% 26$ in villages. While interviewing about law of Village Institutions in 17 April 1940, the number of primary schools in villages stated as 5080, teachers as 6091 and the number of students was 370370 (Yücel, 1993, pp. 304-305). Therefore, Yücel had to focus on education on rural areas and teacher training as the previous minister Saffet Arıkan done in his ministry period (1935-1938). The Project named Village Institutions constructed by Yücel involves a plan that elects 
students from villages, trains them as teacher, trainer and leader, and sends them again to the village. While discussing law of this project (Yücel, 1993, pp. 304-305), his statement shows that these institutions are going to be both educational institutions and practicum sites where people in the villages can benefit for everyday life, get economic income and learn modern life subjects like culture, health, agriculture and animal husbandry.

\section{We did not adopt village institution as an institution that only serves for theoretical training. We did not call it as a school because of practicing a number of activities like agricultural arts, blacksmithing and simple carpentry; we name it as an institution.}

The basic method in all courses and activities in these institutions depends on "learning-by-doing" principle and public education also lies behind the given education there (Binbaşığlu, 1993). The main goals of Village Institutions were to raise education levels of the masses, to create the necessary conditions for the reform establishment, to enable the participation of the public into political, economic and cultural life actively, and to raise people's awareness about their rights in accordance with the populism principles of Atatürk, the founder of Turkish Republic (Tonguç, 1970). Still, the other aim of these institutions was to establish a country that was purified from squirarch-dominant management style in that period- and developed in all aspects involving independent and intellectual individuals. In line with this target, 16400 teachers, 7300 health officers and 8756 educators started to be trained in these institutions in order to serve in villages until 1946 (Binbaşığlu, 1993).

Yücel noticed that transformation movement in education system would not be effective without cultural improvement. Therefore, he aimed to raise education level of the society, ensure all segments of society to be educated and establish a balance between peasants and urban people. By means of creating a vision in culture, he intended to carry Turkish society to a valuable forward position. His vision about translation of foreign pieces which was stated at First Publication Conference in May 1939 clearly shows up his ideas about direction of Turkey and intend of translation movement (Maarif Vekilliği, 1939a, p.12).

Republican Turkey wishing to be an eminent member of Western culture and thought with having determination that has to translate old and new works of civilized world into its own language and strengthen its self about the sense and thought of the world.

In order to reach this vision, 496 classical works, both western and eastern classics, were translated to Turkish language in his ministry period even though translation of 3500 books were completed throughout 200-year period (1728-1928) until his ministry position. The effectiveness of Yücel showed his reputation not only in translation works but also in cultural and educational works in a short time with determined vision and higher levels goals (Eronat, 1997).

The other theme that Yücel focused on was Turkish language issue; improvement of Turkish language, purification of foreign words and being science language were aimed. His words in First Education Congress reflect the vision about Turkish language (Maarif Vekilliği, 1939b, p.16): 
Native language is backbone of our culture issue. Where there is science, there will be definitely language of the science. There is no science without language and will not be. We are on a path that will create Turkish culture and set up science life having national features and the presense of it will be known in all civilizations. Since science is a system that is established through concepts inspired by observations and concepts is shaped by words, Turkish language will be science language.

In order to reach this goal, spelling guide, Turkish and law dictionary were published in his ministry period beside to bringing philosophical and grammatical terms in Turkish language. Furthermore, the basis of science movement was established in Hasan Ali Yücel period in Republican Turkey. His statement in the First Education Congress also shows that Yücel gave importance to culture and science with setting high level targets where Turkish science should be. Besides, Yücel perceived art fields like theatre and opera important for Turkish humanism and he was also supporter of these facilities that artistic activities should be served under the government according to him. In this sense, Yücel took attention to how Turkish humanism would be and the importance of arts in graduation ceremony of State Conservatory for the first graduates in 3 July 1941 with his statements (Yücel, 1993, p. 379):

We perceive representational arts such as theatre and opera as civilization issues. A new phase of Turkish humanism that we believe all humanity apperceive one day will burn with State Conservatory. Turkish humanism is an independent understanding and feeling that gives value to human being without exception and cuts across all boundaries regarding time and place. Whatever its nationality, we foster all works that bring new thought and new feeling to humanity with respect and adoration.

By means of his statements, we understand that Yücel had higher levels goals for Turkish humanity in terms of arts and he was forward thinking leader anticipating that humanity lies behind arts.

Hasan Ali Yücel created high level aims and vision for Turkish culture in addition to anticipating future needs of the society in that years. Yücel expressing his humanist thoughts freely in every place had gained respect of the world. After World War II, he convened to UNESCO meeting in London to sign the establishment of UNESCO with being a representative of Turkey in 4 November 1945. In this meeting, his statements reveal his peaceful and humanist character beside to being forward thinking with realizing the necessity of international education putting into practice as now nations put emphasis on cultural interaction programs like Erasmus, Leonardo Da Vinci, Sokrates (Yücel, 1993, pp. 265-266).

Events of the last years reveal significant role of education in preparing nations for war as well as for peace. People get rid of despise motion with World War II somehow; continuous peace will be acquired by international education with the basis of respecting humans. Reaching information is not enough for people. It is required to instill those peaceful principles.

Yücel was a leader succeeded in being a role model to people that come after him with his educational and cultural initiations. He initiated these events as a start point in 
the related field and he aimed continuation of these events as a tradition. His wished the continuation of these initiatives that presents itself in his closing speech in First Geography Congress (Maarif Vekilliği, 1941, pp. 114-117):

\begin{abstract}
In the last years, some meetings possess an attribute of being the first. Publication Conference was prepared; we called it as first because it has not existed before. Council of Education was convened; in the same way, we called it as 'First Council of Education'. We use the same number while opening this congress. My heart sincerely wishing these firsts will be second, third, fifth, tenth, hundredth and thousandth.
\end{abstract}

First Publication Conference, First Geography Congress, First Council of Education, First Public Painting and Sculpture Exhibition were obvious examples in order to reach this aim. His initiated act has been continued at the present time; 18th Council of Education held on 1 November 2010 and the next Council of Education will be held on the following years.

The other issues that Yücel succeeded with being a role model and the ongoing practices today can be stated as "one type book implementation" and "values education". His thoughts about standard book implementation of the government reveals the purpose lies behind distributing one type book in his speech in First Education Congress (Maarif Vekilliği, 1939b, p. 16):

\begin{abstract}
The government is not only responsible for raising a book writer. The government is raising a book writer but is also responsible for providing students with books that are appropriate for financial and economic situation of the country, whose price and the physical quality are determined through rational principles, and whose content are correct. Furthermore, it is necessary to follow that teaching task in every corner of the country will be the same and all teachers should work with the same method in lectures. We especially must think about it.
\end{abstract}

Even though some governments left one type book initiation after Yücel period, this implementation embraced again with the new government in 2003. In addition, Nabi Avc1 who is new minister of National Education in Turkey has taken over ministry from Ömer Dinçer, the previous minister, and began his duty by thanking Hasan Ali Yücel for his introduction of Eastern and Western principles, and specialists to them and the previous generation. Thus, Yücel can be also seen as a role model to people that come after him in ministry (Memurlar, 2013).

Yücel was an admired and respected leader that UNESCO proclaimed annual years just for five people in Turkish society (Mustafa Kemal Atatürk, Mevlana, Yunus Emre, Nasreddin Hoca and Hasan Ali Yücel) and Yücel was one of these valuable persons. Not only UNESCO celebrated this annual year in 100th anniversary of his birth (1997), but also Yücel's name has been endured to live today. Especially Istanbul University Faculty of Education and schools in almost every province of Turkey possess the name of Hasan Ali Yücel. Furthermore, Ministry of Culture has undertaken the publication of his books since 1993; Atatürkçü Düşünce Derneği awarded Yücel with "1994 Atatürk Prize" and opened a photography exhibition in his name in 1995, Yücel's sculpture has been put in Ankara University Faculty of Fine Arts' garden and his name given to one of the Expolangues Languages, Cultures and International Exchange Exhibition halls in 1996 when Turkey was guest of honour. These events can be accepted as the expressions of respect and admiration for his valuable personality. At 
the same time, Yücel can also be seen as a charismatic leader who took care of his cloths. As it is clear from his photograph (Figure 1), his confident posture, handsomeness and cloth selection are proofs of his charismatic image (Ç1kar, 1998).

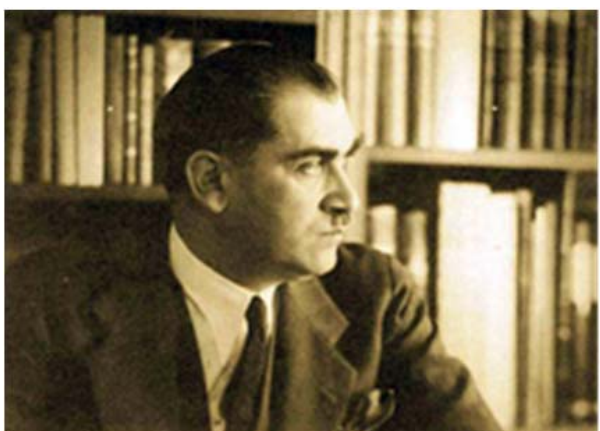

Figure 1. Hasan Ali Yücel [1897-1961]

In charisma and idealized influence aspect, Yücel's another trait that should be mentioned is his ownership about moral and ethical standards. When he was general directorate of Secondary Education before his ministry position, ministry of the period Yusuf Hikmet Bayur wanted Yücel to favour his relative; however, Yücel rejected his request due to its being illegal. Upon his insistence, a discussion was experienced between Yücel and Bayur, and Yücel resigned from his position. Due to being in a difficult situation, minister Bayur apologized from Yücel and Yücel returned to his work (Çıkar, 1998). In another case, when Yücel's son Can Yücel (1926-1999), a famous Turkish poet, and his friend Gazi Yaşargil, a famous Turkish scientist and neurosurgeon (1925-...), graduated from high school (1943), they wanted Ministry of Education to send them abroad for education with their savings. Yet, Yücel made his son out of the room, said Yaşargil "I can send you, but if I send your friend, it will be gossip, they will say 'he sent his son to the abroad', that's why I can't send him." and sent Yaşargil to Switzerland for education. As can be seen from these events, Yücel was a government man adopting ethic principles with being far from favoritism. At the same time, Yücel was a person clearly telling his ideas with being away from flattery. In a conversation with Atatürk, even if the people around Yücel talked Atatürk obsequiously, he answered his question "When Turkish nation assumes itself as saved?" by replying "When Turkish nation doesn't need to search itself a saver, it will be rescued.”, thus Yücel won his respect and admiration (Yücel, 1960, pp. 894-895). In a time when racism reached its climax in Europe and extreme nationalism was prevalent driving nations from each other through various ideologies and assertions, Yücel's statements showed the signs of his humanist and peaceful mentality in UNESCO meeting (Yücel, 1993, p. 267):

It's time to disseminate the principles urging nations to become close to each other and it's time to fasten education to these principles in all over the world. While killing others terribly increasing at the present time, only shelter of the nations will be unwavering friendship ideal. 
Actually, these statements clearly indicate how Yücel's family taught him Mevlana and his thought [Come, come again, whoever you are, come.] with internalizing it from his childhood. Furthermore, Ahmet Hamdi Tanpinar, a famous Turkish writer, who knew Yücel since Turkish War of Independence years stated Yücel's open and honest character by his words in a conference about Hasan Ali Yücel "Ali is a person explicitly expressing himself. He has no hidden and dark side." (Tanpinar, 1961, pp. 16-17). Still the other issue that Yücel focused on and today the education system concentrated is bringing up morally upright individuals; in other words, values education. His words in First Education Congress show the importance that he gave to values education (Maarif Vekilliği, 1939b, p. 6):

The first matter of our national culture is moral education. It is necessary to rethink obligations of the school and to provide students deeper and more extensive expedience and suggestions than today by making practical quality decisions.

\section{Being Source of Inspiration through Initiating Culture Movements}

Yücel was a leader being far away from pessimistic view and having optimistic thought about future of Turkish education. His words are obvious sign how he set off the purpose of education (Yücel, 1947, p. 3):

We won't leave any fading flower behind the mountains, hills, countrysides and even far-flong places in Turkish land through achieving the handled elementary education litigation.

Hasan Ali Yücel was an education leader being source of inspiration to Atatürk about language and culture concepts for shaping language and culture movements in Republican Turkey with his ideas that he put forward. When he was on country trip with Atatürk, Atatürk criticized difficult words that he used in his textbook and asked why he didn't find Turkish translations of these terms. Yücel responded as below (Yücel, 1947, p. 3):

I thought. Even I made some practices; I noticed that these kinds of alterations done by individuals would be unfavorable. If all people use their own way of address, there will be no unity in the expressions and no one understands each other. Hence, I think that commissions and associations will be established and science translations will be studied there.

By his thoughts, he built main stones of Turkish language studies and establishment of Turkish Language Association after two years in 1932. Therefore, it can be suggested that he was committed to set the goal of education and inspired society through initiating culture movements.

Yücel internalized reforms that he made in the field of culture and arts in his behaviors, and was a role model to the followers by his acts. The statement of Prof. Ekrem Akurgal who was a famous Turkish archaeologist best described his internalized behaviors with his expressions (Şengör, 2001):

Hasan Ali breeze was blowing in Ankara in 1940s. He followed every kind of cultural event and gave contributions to these events cordially. Every Saturday, 
he went to listen to the given concert in Conservatory founded by himself in Cebeci, with Ismet Inönü who was president of the ministry in that period.

At the same time, Yücel was a source of inspiration to wide audience of parents and students by establishing a connection through radio and explaining the performed transformations. Likewise, he tried to create awareness on society about education and training and to increase their culture levels while giving a public speech at children and sports celebration and at "domestic goods" weeks (Çıkar, 1998). Thus, it is obvious that he encouraged Turkish society for cultural progress in his speeches and inspired them through motivation for cultural events.

The basic characteristic that Yücel put his mark on Turkish education system perhaps corresponds to giving importance to work as a team. Yücel always created team spirit and cooperation by gathering the country's writers, artists, academicians, ministry personnel, publishers, parliamentarians, teachers and doctors both at First Education Congress and Turkish Publishing Exhibition in order to receive ideas of all concerned parties. These congresses were important due to providing space for discussing the future of education and culture in all aspects and making decions in order to improve the country's education system and culture. Building the same team spirit and handling the issues in depth were also seen in Physical Education and Sports Forum. Yücel invited everyone from sociologists, educators, athletes, presidents of associations, architects to sports writers into this process. This situation provides how he provided the participation of the followers into the process and how he created a tempting vision with the followers through a team spirit (Yücel, 1993). Yücel's statements in closing speech in First Geography Congress in 1941 and in opening speech in the first meeting of First Ancient Monuments and Museums Advisory Commission in 1945 demonstrate the obvious evidence of his success and how much importance given to team spirit and cooperative working by himself (Maarif Vekilliği, 1941, p. 116; Yücel, 1993, p. 225).

Our aim about connecting the works to a thorough program in the Ministry for 6-
7 years demonstrated the efficacy of setting unity of ideas and ideals. Regardless
of the work, working with qualified people and cooperating with each other
always provide good results.

The important feature of the period which reached the highest point of culture and enlightenment movement at the beginning of the 40's and the proposed long term plans were actualized is dynamism. First, the country requirements were detected, then 'collaborative' environment was created, methods and regulations in other countries were examined by contributions of the specialists, comparisons were made and solutions were provided accordingly.

\section{Providing Opportunity for the Enlightenment}

Yücel's ministry period was starting point of creative movements in education and culture. His biggest sounding project Village Institutions, a project for instigating a poor and uneducated nation that experienced resurgence after World War II, indicates his creativity against the existing situations and needs in that years (See Figure 2). Yücel described this creative project in his words when interviewing about law of Village Institutions (Yücel, 1993, pp. 304-305): 
The principle of Village Institutions, this practical principle is totally ours. It is not an imitation. It is Turkish discovery. It is unique. Because it has taken its inspiration from love of the nation. Pedagogy books do not include it, classical pedagogues do not know. They do not know because it is not an educational theory, it is a fundamental principle of national development and an attack to be actualized...

When conditions of that time considered, Village Institutions was a creative solution for teacher training which was mostly discussed in education authorities. Development and enlightenment were needed to begin villages at first in 1940s Turkey since great majority of people was living in villages. Thus, this enlightenment and development project expected to be initiated by teachers (Binbaşığlu, 1993).

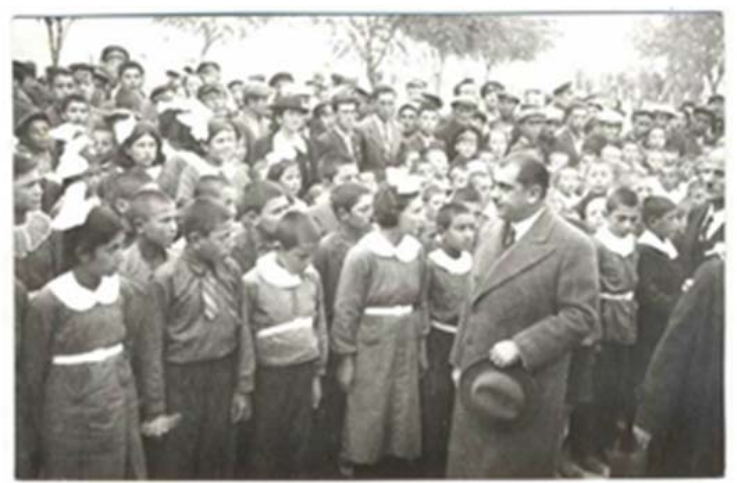

Figure 2. While visiting Village Institutions

Creative movements in the field of education were not limited only by Village Institutions. Arrangements in vocational education and higher education have constituted other steps of his reform movements in education system. Due to giving importance to vocational education and restructuring the Ministry, Yücel restructured two types of undersecretary named General Education Undersecretary and Vocational Education Undersecretary in 1941. Still other regulation on vocational education that Yücel ensured was the acceptance of Opening and Upgrading Vocational and Technical Schools Act [Act No 4309]. With this Act, vocational educational studies were regularized, the number of vocational education schools increased from 113 to 275 and vocational education courses increased their number from 42 to 470 in nationwide as well (Doğan, 1983). Reforms in higher education system followed changes in vocational education. Yücel's the soundest enterprise in development of Turkish universities was Universities Act [Act No 4936] in 13 June 1946 when he was in the last year of his minister position. This act played a significant role in planning of disbanding universities' dependency to Ministry of National Education; becoming autonomous institutions in terms of budget, education and management; giving importance to research rather than espousing traditional education; development of Turkey and solving problems of higher education (Widmann, 1981). Yücel period also corresponds to foundation of today's most respected universities. Yücel established İstanbul Technical University (1944) whose roots come from Ottoman Empire and has been directing Turkish science policies today; Ankara University (1946) whose 
foundations laid by Atatürk was also established by Yücel. Another issue that Yücel attached importance was the place of sport on youths' education. The first movement coming from Yücel in his minister position about this issue was unifying General Physical Education Directorate with his ministry on 29 May 1942. He wanted the directorate to investigate how and in what conditions youth performed sports classes. In this respect, Physical Education and Sports Forum was organized on 18 February 1946 with the participation of various occupational groups in order to determine problems and deficiencies of sports in Turkey beside to making decisions about future studies (Yücel, 1993).

Hasan Ali was a leader providing opportunities for cultural and artistic facilities with contributing to Western art by adding Turkish harmony that Turkish society was not accustomed to and introducing different branches of art such as painting, sculpture, music, opera, theater and ballet with Turkish society. Key initiations in arts brought to life in his ministry period during Republican period. Yücel responded politicians while negotiating State Conservatory in Turkish Grand National Assembly by criticizing these branches of art due to not being national at that time (Yücel, 1993, pp. 323-324):

We accepted values of human community. This should not mean that we leave Turkishness. Is it possible that being civilized prohibit being Turkish? We are Turkish; not just our traditional music, but all we have is national.

In order to raise students in the fields of music, theatre, opera and ballet with this mind, Ankara State Conservatory was established. Besides, First Painting and Sculpture Exhibition was organized in order to exhibit the works in painting and sculpture.

In parallel with arts, the other areas that Yücel gave importance and providing opportunity to modernize were museums and exhibition of ancient monuments. For the purpose of exhibiting unique works in Turkish culture and carrying out these activities regularly, Yücel established General Directorate of Antiques and Museums in 1944, Aşiyan Museum in 1945 in memory of famous Turkish poet Tevfik Fikret and organized First Ancient Monuments and Museums Advisory Commission with participation of various communities (Yücel, 1993). This Advisory Commission aimed to detect, restorate and conservate ancient monuments, and to prompt museological activities. At the same time, Yücel perceived this subject as an important part of education as it is clear from his opening speech in the first meeting of First Ancient Monuments and Museums Advisory Commission (Yücel, 1993, pp. 221-227):

We should know better that when culture is restricted to school alone, there will be no cultural integrity in that country. It is difficult to believe that culture of a school will be strong in a city without library, museum and theatre. Therefore, I see museums as schools on their own.

Still the other step for enlightenment of Turkish society was translation and literature act initiated by Yücel. In order to arrange translation and encyclopedia movements, plan printing and publishing works and determine the works that will be translated, First Turkish Publication Congress was organized and an unprecedented translation act began (Maarif Vekilliği, 1939a). By means of this act, 496 works of the eastern and western classics were translated into Turkish in Translation Office which 
was established in Yücel's 7-years of ministry period (Ertuğrul, 1997). Yücel who wrote 56 books reflects the importance that he gave to literature and translation in his words (Yücel, 1941):

The first understanding and feeling stage of humanism spirit starts with internalizing of art works that are particular expressions of human existence. Of the art branches, literature has the richest consciousness elements for this expression. Thus, it is a nation's repetition of other countries' literature in its own language, or rather in its own comprehension; increase, vitalize and recreate its power of intelligence and understanding in proportion to that works.

Yücel also supported translation and literary enterprises with encyclopedia and journal studies by decisions taken in First Publishing Congress. For the purpose of a better understanding of Turkish culture and the religion of Islam, he prepared the ground for enlightenment by establishing an Encyclopedia Office, publishing the first volumes of Turkish [İnönü] and Islam Encylopedias and giving a start to translation of Grand Memento Larousse in 1942. In the field of journal publishing, Journal of Translation [Tercüme dergisi], hosting translation works, Primary Education [İlköğretim], Notifications [Tebliğler], Fine Arts [Güzel Sanatlar], Technical Education [Teknik Öğretim], Village Institutions [Köy Enstitüleri] and Woman-house journals were began to be published (Ç1kar, 1998). Yücel's Turkish language studies were also added to these cultural initiatives. As mentioned above, in order to achieve Turkish language as science language and to refine it, spelling and term guides like Turkish Spelling Guide (1941), Grammar Terms (1942), Geography Terms (1942), Philosophy Terms (1942), Law Dictionary (1942) and Turkish Dictionary (1944) were published (Coşkun, 2007).

Yücel's other characteristic on his transformational leadership was his approach to old events with a new perspective. Different from previous education ministers, he possessed a holistic perspective towards educational issues. He emphasized that the process of education was not only comprised of primary education; all stages up to higher education should be meticulously dwelled on. The reason for why he carried out reform movements in all levels from primary education to higher education can be understood from his statements (Yücel, 1993, p. 297):

\begin{abstract}
When we look our history of education briefly, in a hundred-year cycle since Tanzimat period, our education studies have just stayed in ministry or had an imitation property with very few expections, and certain facades of the studies tried to be solved in certain times by adaptations. However, due to not being one sided facade, the culture of a nation should be studied in detail with a synthetic eye, I believe. That is why we need to handle Turkish education not only in primary education origin, but we should consider it as a whole from primary education toward universities and academies without neglecting any side of it.
\end{abstract}

His perspective about ministry was to create a ministry of education which operating itself without a minister, has non-changing policies even if the minister changes, and moving with its unique vision and goals. He mentioned his perspective about ministry of education as follows (Yücel, 1974, p. 104):

When will ministries become organizations that function without any minister? That's the whole point here. We have seen such countries that new government had not formed for weeks, ministers were unable to be elected, but ministries 
worked perfectly. We need this common principle: minister comes and goes, but the ministry stays permanent.

Reforms in Yücel period should not be seen as the only practices in the field of education and culture; these reforms can be approached as opportunity providing for the followers'creativity. Translation act of the classics, journal publishing and publishing activities showed its creativity influence on poem and contemporary literature of a short time later (Gürsel, 1983). These kinds of culture movements not only showed themselves in literature, but also they stood out in education; modernism was generated beside to development of the world of thought in Turkish youth. The same situation was also actualized by Village Institutions. Teachers who went to Village Institutions would not be an ordinary village teacher; on the contrary, they would be models for the peasants with regards to education, culture, health, agriculture, animal husbandry, and modern life concerns, help them about these issues for enlightenment, and ensure them to become creative individuals by maintaining their vital activities and playing an effective role in the targeted modernism project.

\section{Considering Individual Needs and Growth}

When Yücel's transformative leadership is examined from individualized consideration perspective, it is clear that he showed many characteristics of this aspect. He was democratic, participatory and put special emphasis to followers' needs for developing their personal development. Yücel conducted mentioned reforms for the purpose of the followers' development, Turkish society's growth and taking place between developed countries.

Yücel was a democratic leader respecting ideas and opinions of his colleagues, accepting individual differences and complying with majority decision. His characteristics about this aspect can be understood from his opening speech in the first meeting of First Ancient Monuments and Museums Advisory Commission (Yücel, 1993, p. 225):

\section{The most fundamental rule during ministry studies is minorities' maintenance of their idea and complying with the majority even though degree of the disagreement.}

The importance that he gave the thoughts of teachers as the followers is obviously seen on the journals of "Primary Education" and "Notifications". Indeed, these journals were not solely one-way communication tools declaring directives of the Ministry; but also a communication tool that teachers noticed their thoughts and views to the Ministry (Yücel, 1993). At the same time, Yücel gave importance to followers' individual growth and encouraged them. Specifically, the other purposes of establishment of First Public Painting and Sculpture Exhibition and Ankara State Conservatory were to encourage art and the artists. After his initiatives, the government has taken the functions of encouraging, developing art and the artists through preparing exhibitions, promoting artists as government staff, and arranging artistic and cultural activities until today. 


\section{DISCUSSION \& CONCLUSION}

Educational transformations in Turkey started 1850s, speeded up after Tanzimat Period and turned into more structured and aimed education policies with the Republican Period. Indeed, education was utilized as a strategic and political instrument in the founding years of the Republic of Turkey and it was believed by the founders of the Republic that education is the main determinant of social, political, cultural and economic changes and it has a driving force. Even though the all controversy and criticisms, the person who implemented this belief, started and carried on educational reforms, initiated cultural transformations, provided new perspectives on language, arts and literature with being one of the important educational leaders in our history is said to be Hasan Ali Yücel. Specifically, the study investigating Hasan Ali Yücel from transformational leadership perspective of Bass (1984) concludes that many characteristics of Hasan Ali Yücel shows that he was a transformational leader. If Yücel's transformational leadership is taken under charisma and idealized influence aspect, his analysis about present status of Turkey in that period, setting a vision for followers with high expectations and actualizing Village Institutions, arranging studies regarding translation, language, theatre and opera are said to increase education level of the society in a short time beside to acculturation, enlightenment and development. Yücel had a humanist character putting ideas that have enlightened the present day as well as his ministry period and he was a far-sighted leader emphasizing intercultural education which is put into practice today. At the same time, he brought the first important studies to life with shaping Turkish education and culture as being a role model to people come after him. Specifically, 19th Council of Education held on 4-6 December 2014 and the next Council of Education was going to be held on the following years. The other trait that leaders should have as regards charisma and idealized influence is arousing respect (Bass \& Avolio, 1995). In fact, Yücel was an admired and respected leader not only in Turkey but also in worldwide that UNESCO proclaimed the year 1997 as an annual year on behalf of Hasan Ali Yücel. In addition to having a respected character, transformational leaders possess moral and ethical tenets on their personalities (Bass \& Avolio, 1995). In accordance with this, Yücel was a public servant who was far from favoritism in government works with being honest and open. Moreover, he had a humanist character accepting humanity as a whole against racism and extreme nationalism that was prevalent in Europe at that time.

In terms of inspirational motivation, it can be concluded that Hasan Ali Yücel had transformational leadership traits regarding having optimistic thought about the future of Turkish education and pioneering the idea of establishing Turkish Language Association which was established by Atatürk and also serves for Turkish language studies today. Besides, internalizing reforms that he made in the field of culture and arts in his behaviors shows his transformational leader characteristic. Yücel also gave importance to work as a team while implementing changes on Turkish education system with a tempting vision for the followers that can be considered under his inspirational motivation.

As regards intellectual stimulation, transformational leaders are perceived as creative individuals (Bass \& Avolio, 1993). Hasan Ali Yücel provided first fundamental education and culture movements in Republic of Turkey; by presenting new education institutions to the world, regulating higher education and enabling universities as autonomous institutions in terms of budget, education and management, arranging 
vocational education studies, restructuring of Turkish Ministry of National Education, introducing various branches of art such as painting, sculpture, music, opera, theater and ballet with Turkish society, promoting artists as government staff and providing institutions to raise people in these artistic fields, modernizing museums, doing studies for enabling Turkish language as science language, and bringing classical works into Turkish language through translation act. His endeavors prove his creativeness in many fields. Besides, approaching to old events with a new perspective is another characteristic of transformational leaders in that aspect (Bass \& Avolio, 1993). Yücel's difference from previous education ministers is his holistic perspective towards educational issues without perceiving primary education, secondary education and higher education as separate stages. In fact, he is different from other ministers with his efforts in creating a ministry that systematically functions. Furthermore, educational and cultural reforms performed by him have positive influence on followers through providing opportunities for their creativity. His acts on reforms and providing opportunities for followers can be considered as his transformational leader characteristic that Turkey has proceeded to attach on literature, art, education and social development after his reforms.

In individualized consideration perspective, it can be said that Yücel bears some features consistent with traits of a transformational leader. His democratic and participatory personality, putting special emphasis on needs of Turkish society in all reforms and making efforts for developing personal development of the followers point his characteristics as a transformative leader.

Lastly, it can be concluded that even though Turkey has the most comprehensive educational experience since 1950s, Turkey has stayed weak in developing unique educational models without taking advantage of this experience. Therefore, it can be suggested for future research that important leaders in our educational history are required to be examined and discussed in their own context in leadership studies as well as in education and teaching training fields. Based on these leadership characteristics and experiences, comprehensive biographical studies can be suggested for future research in order to contribute to leadership theories with unique context.

\section{KAYNAKÇA/REFERENCES}

Avolio, B. J., \& Bass, B. M. (1988). Transformational leadership, charisma, and beyond. In J. G. Hunt, B. R. Baliga, H. P. Dachler, \& C. A. Schriesheim (Eds.), Emerging leadership vitas (pp. 29-49). Lexington, MA: Lexington Books.

Balyer, A. (2012). Transformational leadership behaviors of school principals: A qualitative research based on teachers' perceptions. International Online Journal of Educational Sciences, 4(3), 581-591.

Barling, J., Moutinho, S., \& Kelloway, E. K. (1998). Transformational leadership and group performance: The mediating role of affective commitment. Manuscript submitted for publication. Kingston, Ontario: Queen's University.

Barling, J., Weber, T., \& Kelloway, E. K. (1996). Effects of transformational leadership training and attitudinal and financial outcomes: A field experiment. Journal of Applied Psychology, 81(6), 827-832.

Bass, B. M. (1985). Leadership and performance beyond expectations. New York: Free Press. 
Bass, B. M. (1990). From transactional to transformational leadership: Learning to share the vision. Organizational Dynamics, 18, 19-31.

Bass, B. M. (1998). The ethics of transformational leadership. In J. Ciulla (Ed.), Ethics: The hearth of leadership (pp.169-192). Wesport, CT: Praeger.

Bass, B. M, \& Avolio, B. J. (1990). The implications of transactional and transformational leadership for individual, team, and organizational development. Research in Organizational Change and Development, 4, 231-272.

Bass, B. M, \& Avolio, B. J. (1993). Transformational leadership: A response to critiques. In M. M. Chemers \& R. Ayman (Eds.), Leadership theory and research: Perspectives and directions (pp. 49-80). San Diego, CA: Academic Press.

Bass, B. M, \& Avolio, B. J. (1994). Improving organizational effectiveness through transformational leadership. Thousand Oaks, CA: Sage.

Bass, B. M., \& Avolio, B. J. (1995). The multifactor leadership questionnaire form 5x. Palo Alto, CA: Mind Garden.

Bennis, W. G., \& Nanus, B. (1985). Leaders: The strategies for taking charge. New York: Harper \& Row.

Binbaşığlu, C. (1993). Çağdaş eğitim ve köy enstitüleri: Tarihsel bir çerçeve. İzmir: Dikili Etki Ofset.

Boerner, S., Eisenbeiss, S. A., \& Griesser, D. (2007). Follower behavior and organizational performance: The impact of transformational leaders. Journal of Leadership \& Organizational Studies, 13(3), 15-26.

Bolden, R., Gosling, J., Marturano, A., \& Dennison, P. (2003). A review of leadership theory and competency frameworks. Edited version of a report for Chase Consulting and The Management Standards Centre.

Burns, J. M. (1978). Leadership. New York: Harper \& Row.

Chase, S.E. (2005). Narrative inquiry: Multiple lenses, approaches, voices. In N.K. Denzin \& Y.S. Lincoln (Eds.), The Sage Handbook of Qualitative Research (pp. 651-679). Thousand Oaks CA: Sage Publications.

Creswell, J. W. (2007). Qualitative inquiry and research design: Choosing among five approaches (2nd ed.). Thousand Oaks, CA: Sage Publications.

Coşkun, A. (2007). Hasan Ali Yücel: Aydınlanma devrimcisi. İstanbul: Cumhuriyet Kitaplar1.

Covey, S. (1992). Principle-centered leadership. New York: Simon and Schuster.

Czarniawska, B. (2004). Narratives in social science research. Thousand Oaks, CA: Sage Publications.

Çıkar, M. (1998). Hasan Ali Yücel ve Türk Kültür Reformu (2nd ed.). Ankara: Türkiye İş Bankası Kültür Yayınları.

Denzin, N. K. (1989). Interpretative biography. Newbury Park, CA: Sage Publications.

Doğan, H. (1983). Cumhuriyet döneminde eğitim. İstanbul: MEB Bilim ve Kültür Eserler Dizisi.

Downtown, J. V. (1973). Rebel leadership: Commitment and charisma in a revolutionary process. New York: Free Press.

Eronat, C. Y. (1997). Aydınlanmanın hızı. In M.Coşturoğlu and M. Emiroğlu (Eds.), Hasan Ali Yücel'e Armă̆an (pp.7-45). Ankara: Birleşmiş Milletler Türk Derneği Yayınları.

Ertuğrul, F. (1997). Yücel-Öner davası: In M.Coşturoğlu and M. Emiroğlu (Eds.), Hasan Ali Yücel'e Armağan (pp.X-X). Ankara: Birleşmiş Milletler Türk Derneği Yayınları.

Forster, N. (1995). The analysis of company documentation. In C. Cassell \& G. Symon (Eds.), Qualitative methods in organizational research: A practical guide (pp. 147166). London: Sage Publications. 
Gronn, P., \& Ribbins, P. (1996). Leaders in context: Postpositivist approaches to understanding educational leadership. Educational Administration Quarterly, 32(3), 452-473.

Gürsel, N. (1983). Uygarlık ve çeviri. In Murat Belge (Ed.), Cumhuriyet Dönemi Türk Ansiklopedisi (pp.320-323, Vol. II). İstanbul: İletişim Yayınları.

Hatter, J. J., \& Bass, B. M. (1988). Superiors' evaluations and subordinates' perceptions of transformational and transactional leadership. Journal of Applied Psychology, 73, 695702.

Howell, J. M., \& Avolio, B. J. (1993). Transformational leadership, transactional leadership, locus of control and support for innovation: Key predictors of consolidated-businessunit performance. Journal of Applied Psychology, 78, 891-902.

Jorg, F., \& Schyns, B. (2004). Is similarity in leadership related to organizational outcomes? The case of transformational leadership. Journal of Leadership \& Organizational Studies, 10(4), 92-102.

Koh, W. L., Steers, R. M., \& Terborg, J. R. (1995). The effects of transformational leadership on teacher attitudes and student performance in Singapore. Journal of Organizational Development, 16, 319-333.

Kirkpatrick, S. A., \& Locke, E. A. (1996). Direct and indirect effects of three core charismatic leadership components on performance and attitudes. Journal of Applied Psychology, 81, 36-51.

Leithwood, K. (1994). Leadership for school restructuring. Educational Administration Quarterly, 30(4), 498-518.

Lincoln,Y. S \& Guba, E. G. (1985). Naturalistic inquiry. Beverly Hills: Sage.

Maarif Vekilliği (1939a). Birinci Türk Neşriyat Kongresi (1-5 May 1939): Raporlar, teklifler, müzakere zabıtları. Ankara: Edebiyatçılar Derneği, T.C. Maarif Vekilliği.

Maarif Vekilliği (1939b). Birinci Maarif Şurası (17-29 July 1939): Çalışma programı, konuşmalar, lahikalar. Ankara: T.C. Maarif Vekilliği.

Maarif Vekilliği (1941). Birinci Coğrafya Kongresi (6-21 June 1941): Raporlar, müzakereler, kararlar. Ankara: T.C. Maarif Vekilliği.

Memurlar (2013). Dinçer görevini Nabi Avcı'ya devretti. Retrieved February 10, 2013, from www.memurlar.net/haber/332272.

Miles, M. B., \& Huberman, A. M. (1994). An expanded sourcebook: qualitative data analysis. Thousand Oaks: Sage Publications.

Northouse, P. G. (2007). Leadership: Theory and practice. Thousand Oaks, California: Sage Publications.

Shamir, B., Dayan-Horesh, H., \& Adler, D. (2005). Leading by biography: Towards a lifestory approach to the study of leadership. Leadership, 1(1), 13-29.

Şengör, A. M. C. (2001). Hasan Ali Yücel ve Türk aydınlanması. Ankara: Tübitak Yayınları.

Tanpınar, A. H. (1961). Yücel toplantısı. Imece, 1(2), 16-17.

Tichy, N. M., \& Devanna, M. A. (1986). The transformational leader. New York: Wiley.

Tonguç, E. (1970). Devrim açısından köy enstitüleri ve Tonguç. İstanbul: Ant Yayınları.

Veland, T. D. (2012). A study of leadership dispositions of transformational leaders in Georgia High School. Georgia Southern University Electronic Thesis \& Dissertations.

Widmann, H. (1981). Atatürk üniversite reformu (Almanca konuşulan ülkelerden 1933 yılından sonra Türkiye'ye gelen ögretim üyeleri) yaşam öyküleri, çalışmaları, etkileri (A. Kazancigil \& S. Bozkurt, Trans.). İstanbul: İstanbul Üniversitesi, Cerrahpaşa Tip Fakültesi Özel Seri 3. 
Xavier, P. (2013). Transformational leadership: A qualitative study of ruralelementary schools in Fresno County. Unpublished Doctoral Dissertation. Loyols Marymount University.

Yammarino, F. J., \& Bass, B. M. (1990). Transformational leadership and multiple levels of analysis. Human Relations, 43(10), 975-995.

Yu, H., Leithwood, K., \& Jantzi, D. (2002). The effects of transformational leadership on teachers' commitment to change in Hong Kong. Journal of Educational Administration, 40(4), 368-89.

Yukl, G. (2010). Leadership in organizations (7th ed.). Englewoods Cliffs, NJ: Prentice Hall.

Yücel, H. A. (1941). Klasiklere birinci önsöz. In Oscar Wilde, Hikayeler (N. Sevin, Trans., pp. 1-5). İstanbul: MEB.

Yücel, H. A. (1947, September 10). Hasan Ali Yücel sıfır meselesini anlatıyor. Yeni Gazete, 3.

Yücel, H. A. (1960). Hürriyet gene hürriyet (Vol. 2). Ankara: Türk Tarih Kurumu.

Yücel, H. A. (1974). Kültür üzerine düşünceler. Ankara: Türkiye İş Bankası Kültür Yayınları.

Yücel, H. A. (1990). Geçtiğim günlerden (2 ${ }^{\text {nd }}$ ed.). İstanbul: İletişim Yayınları.

Yücel, H. A. (1993). Milli eğitimle ilgili söylev ve demeçler. İçel: Kültür Bakanlığı Yayınları.

\section{İletișim/Correspondence}

Gökhan KILIÇOĞLU

Eskişehir Osmangazi University, Faculty of Education,

Department of Educational Sciences

gkilicoglu@outlook.com 